\title{
Radicalizing electoral system effects on support for nationalist hardliners in Serbia
}

\author{
Bochsler, Daniel
}

\begin{abstract}
This paper investigates electoral outcomes produced by the two-round majority system in ethnically divided societies. Earlier studies, focused mainly on the Southern American states, have revealed that in ethnically mixed environments, competitors with radical positions on ethnic issues perform particularly well. This paper extends this idea to municipal elections in Serbia, showing how radical majority nationalist parties exhibit particularly strong performances in ethnically mixed municipalities. While this effect is also apparent under proportional representation, we argue that it is much stronger when a two-round majority vote system is employed.
\end{abstract}

DOI: https://doi.org/10.1111/j.1469-8129.2012.00558.x

Posted at the Zurich Open Repository and Archive, University of Zurich ZORA URL: https://doi.org/10.5167/uzh-88070

Journal Article

Accepted Version

Originally published at:

Bochsler, Daniel (2013). Radicalizing electoral system effects on support for nationalist hardliners in Serbia. Nations and Nationalism, 19(1):21-43.

DOI: https://doi.org/10.1111/j.1469-8129.2012.00558.x 


\title{
Radicalizing Electoral System Effects on Support for Nationalist Hardliners
}

Daniel Bochsler, NCCR Democracy, University of Zurich

(Forthcoming in Nations and Nationalism - this version: 30 March 2012)

\begin{abstract}
This paper investigates electoral outcomes produced by the two-round majority system in ethnically divided societies. Earlier studies, many of them focused on the southern US States, have revealed that in ethnically mixed environments, competitors with radical positions on ethnic issues perform particularly well. This paper extends this idea to municipal elections in Serbia, showing how radical majority nationalist parties exhibit particularly strong performances in ethnically mixed municipalities. While this effect is also apparent under PR, we argue that it is much stronger when a two-round majority vote system is employed.
\end{abstract}

Keywords: ethnic conflict; centripetalism; electoral systems; Serbia.

\section{Introduction ${ }^{1}$}

Can electoral engineers help promote reconciliation between ethnic groups and reduce conflicts? Electoral systems are among the key elements of constitutional design for democratising countries, and there is wide consensus among scholars of electoral systems that they can affect the dynamics of ethnic conflicts. The power-sharing school holds that proportional representation (PR) with large districts, or specially designed districts for ethnic minorities, may serve as a way to better include minority groups in politics (Lijphart 1986; Norris 2005; Doorenspleet 2005: 366; Rule and Zimmerman 1994, etc.). Another group of scholars follow Donald Horowitz in his criticism that PR-based power-sharing regimes contribute to social segmentation. This centripetalist group argues that electoral systems with preference votes may contribute to inter-ethnic conciliation, and the Alternative Vote is the favourite choice, as candidates are only elected with an absolute majority of the votes (Horowitz 1991: 191). In a nutshell, they hold that if candidates need to amass $50 \%$ of available votes in order to be elected in an ethnically mixed district, and if voters can express

\footnotetext{
${ }^{1}$ I am extremely grateful to Bernard Grofman for very thoughtful advise, and for encouraging me to continue with this research. Hanspeter Kriesi, Jon Fraenkel, David Pupovac and two anonymous reviewers who provided very helpful comments. Earlier versions of this paper were presented at the 1st ECPR Graduate Conference, Essex, 7-9 September 2006, the ECPR Summer School on Analytical Politics and Public Choice, Turku, 19-28 September 2007, and at the Conference "Reforming the French Presidential Election System", 15-16 June 2009, Paris. Further, I am very grateful to several interview partners in Serbia, and to Dragan Milošević and Zorica Ćosić, who provided me with detailed data on the municipal elections in Serbia. The Swiss National Research Foundation has generously funded parts of this research.
} 
several preferences, they might then cast their second vote for candidates with a conciliating program (Reilly 2001; Horowitz 2003; Reynolds 2006; Horowitz 1985). While they mainly recommend the Alternative Vote for divided societies, including Western Balkan countries such as Bosnia and Herzegovina (International Crisis Group 1998a), the two-round majority shares many of its features (Grofman forthcoming). One aim of this study is to ascertain whether a conciliation effect, which analysts have found to occur where the Alternative Vote is in force (but see Fraenkel and Grofman 2004, 2006a; 2006b for a more critical view), might similarly be observed for the two-round majority vote.

In this paper, we set out to compare the effect of PR elections and the majoritarian vote on political radicalisation in Serbia, using two nearly-simultaneous elections: a local mayoral election (which used the two-round majority vote), and a national parliamentary election (PR). In keeping with our research goals, we considered these two elections in the context of an ethnically divided society. Note also that one of the countries, in which the Alternative Vote has been discussed is Serbia's neighbour Bosnia and Herzegovina, a country where similar conciliating effects might result, but where the ethnic divide and tensions are even stronger.

The academic literature on racially motivated voting behaviour has suggested that electoral systems' impact on divided societies is highly context-sensitive. Vladimir O. Key has suggested, for instance, that voters from the majority community might vote differently if they lived in contexts with a strong politicisation of ethnic or racial differences. If voters of the majority are confronted with a conspicuous ethnic or racial minority in a majoritarian electoral system, they might move to defeat a candidate whom they expect to be close to the minority-i.e., they will vote for candidates who seem to guarantee the enduring dominance of the majority. In the southern states of the US, this engendered a paradox in the post-WWII period: in environments with an increasing share of racial minorities, politicians who were hostile towards these minorities had increased chances of winning votes and getting elected (Key 1949; Keech 1968; Wright 1977; Glazer et al. 1998; Grofman and Handley 1995, etc.). With this in mind, one might doubt whether the application of majoritiarian electoral systems helps to conciliate politics in divided contexts. Indeed, it seems instead to accelerate radicalisation.

Key's effect builds on the radicalisation of majority voters in dualist or multi-ethnic environments, and accordingly, we expect radical competitors to perform better, especially under majoritarian voting systems. We should also expect radical competitors from the dominant community to do better in multi-ethnic environments than in those which are more 
ethnically homogeneous. Furthermore, in contrast to the centripetalist school, I expect this effect to be accelerated by majoritarian voting systems.

This study allows for a comparison of two electoral systems. In less than a year, Serbian voters were called to the polls to elect the national parliament in December 2003, by list-PR with a 5\% legal threshold and a single nationwide constituency, and to elect local authorities in September 2004, including the election of mayors in two rounds with a majority vote system. ${ }^{1}$ Serbia has recently experienced tensions with several ethnic minorities, and consequently, fits the picture of an ethnically divided society well. ${ }^{2}$

The empirical analysis finds preliminary support for two kinds of radicalisation effects. Especially, it shows that a second type of effect comes into play which implies that radicalisation is stronger under majoritarian electoral systems than under PR systems. The Serbian case is possibly the first analysis which allows an empirical distinction of the two effects. If such a finding could be generalised to all majoritarian voting systems, and to other countries, this would have wide-reaching consequences for electoral system design in divided societies.

The following section summarizes the relevant portion of the academic literature on voting behaviour in ethnically divided societies. It is succeeded by the empirical discussion, with a section on the Serbian party system and electoral system, followed by a section investigating the elections of the local mayors. Then I provide a general discussion.

\section{Explaining radicalisation in mixed-ethnic environments}

Ethnicity and ethnic divides - defined here using citizens' ethnic self-identification ${ }^{3}$ - have frequently engendered political divides. These have been reflected in the formation of ethnic political parties, and have been shown conclusively to affect voting behaviour (Horowitz 1985; Birnir 2007; Chandra 2004, 2005; Van Cott 2005; Norris 2004: 209-29). When the ethnic conflict between two or more groups plays an overwhelmingly important role in political life, scholars speak of divided societies (Reilly 2002; Grofman and Stockwell 2003, to name a few). Multi-ethnic parties — which include ethnic minorities and the largest ethnic group in a country ${ }^{4}$-remain rare in divided societies (Nordlinger 1972; Horowitz 1985; Grofman and Stockwell 2003).

Previous research has emphasised factors that motivate the creation and determine the success of ethnically based parties (Tronconi 2006). The power-sharing school holds that proportional and decentralised institutions are best for divided societies, while majoritarian institutions exclude minorities from political power, allowing the dominance of the majority 
group (Sisk 1996; Lijphart 1968, 1994, 2004; Hartzell and Hoddie 2003; see Andweg 2000 for a review). Some studies have focused particularly on the design of electoral districts and the resultant consequences for the representation of racial minorities (Gerber et al. 1998; Lublin 1999; Scarrow 1999; Richardson and Cooper 2003, etc.). ${ }^{5}$

Looking at the political positioning of the representatives in ethnically divided societies, there are different expectations, and each of them leads to different implications for the choice of political institutions for multi-ethnic contests. We contrast the centripetalist school, which posits that majority-based electoral systems are the best choice, as they strengthen candidates in the political centre, with two opposing models, both looking at processes of radicalisation.

Studying electoral behaviour in the US South, Key (1949) and Keech (1968) have highlighted a seemingly paradoxical phenomenon, in which liberal candidates or parties begin to lose electoral support as the share of minorities increases in an electoral district. This should be more than astonishing. If most minorities support liberal parties or candidates, liberal candidates should have better chances of being elected in constituencies with a relevant minority population. However, the contrary proved to be true. In an ethnically divided environment, members of the majority group were reluctant to support Democratic candidates who they perceived to be too close to the black community.

There are two possible explanations of Key's effect. One of them is the threat hypothesis, which explains radicalisation due to radical political preferences. Local contact with other ethnic groups is associated with a perception of ethnic competition and fears of losing political control over the territory and economic privileges (Blalock 1967: chapter 5; Olzak 1986; Tolbert 2003). This directly translates into more pronounced and more radical preferences on ethnic-nationalist questions, whatever voting rules apply. This might still lead to electoral system effects which emanate from the distribution of voting preferences on electoral districts.

We suggest a different explanation of Key's effect, and rely therefore on a model by Glazer and colleagues (1998). Here, the effect is not based on exogenous preferences, but rather on context-specific institutional effects, which affect voting behaviour among the ethnic majority. While there are groups of voters of the ethnic majority with nationalist preferences who vote for nationalist candidates, and others with moderate preferences who vote for conciliating candidates (if available), the radicalisation effect in this model relies on a third group of voters with fluctuating voting behaviour. They belong to the majority, and have a strong ethnically based political identity, but no hard-line nationalist preferences, i.e. they do not oppose conciliation. However, because they perceive political representation through 
the ethnic lens, they do not vote for candidates who might represent minority interests, let alone for candidates belonging to the minority group. These voters would usually vote for a moderately nationalist or a moderate candidate of their own ethnic group. However, in situations where a candidate is perceived to profit from the votes of the ethnic minority, such ethnically oriented voters of the majority group might switch to a nationalist candidate.

Glazer et al. have applied this model (expressed in slightly different terms) to elections under plurality vote in the US, where often two major candidates stand in elections. In contrast, we differentiate effects by electoral systems. Systems which favour two-candidate races, in ethnically mixed contexts, often lead to a race between a nationalist candidate of the majority versus a candidate of the ethnic minority, or a moderate of the ethnic majority. If the elections are restricted to two candidates, then Key's effect of ethnically oriented voters might come into play, as those voters will favour the nationalist candidate of their own ethnicity (cf. Glazer et al. 1998: 24). This would not happen in ethnically homogeneous contexts, as all candidates would be solely supported by the same ethnic group, so that there would be no reason for ethnically oriented voters not to vote for a moderate. We argue that the same effect does not apply under proportional representation, because a large range of parties allows voters to choose the most appropriate one according to their political preferences, and the choice of candidates gives them the possibility to vote for a moderate (nationalist) party of their ethnicity. Of particular interest however, are two-round majority runoff systems where supposedly in a first round, with a wide field of candidates, the radicalisation effect of ethnically oriented voters should not play a role, but affects the voting behaviour in multiethnic contexts in the second round with only two candidates.

Empirical studies looking at Key's effect have so far focused mainly on plurality elections in the United States (Key 1949; Keech 1968; Wright 1977; Black 1978; Grofman et al. 1992; Grofman and Handley 1995; Glazer et al. 1998, to mention a few). ${ }^{6}$ As we expect differences between different types of electoral systems, we are trying to widen the scope empirically, looking at situations where we can measure the effect under different electoral systems.

In their empirical application, the two models on Key's effect lead to different hypotheses, which again are in contradiction to the centripetal hypothesis discussed in the introduction of this paper. The contact hypothesis, based on radical political preferences, expects that voters in multi-ethnic contexts tend to more nationalist parties under any electoral system. The hypothesis based on ethnically oriented voters expects a bonus for radical candidates in multiethnic environments under the plurality vote or any majoritarian voting system. Finally, both these hypotheses challenge the centripetal hypothesis, which expects that majoritarian voting 
systems lead to the election of more conciliating candidates in multi-ethnic contexts than other types of electoral systems do. While there might be differences between different types of majoritarian electoral systems (Birch 2003; Grofman forthcoming), the centripetal model, but also the hypothesis which expects a radical bonus of the majority vote, is based on their requiring an absolute majority for candidates to be elected, which in the end leads to a competition between two main candidates.

\section{Studying Key's effect in Serbia}

Empirically, this article investigates the hypothesis of radicalisation in multi-ethnic environments under the majority vote, with the agenda of testing the appropriateness of the expected centripetal effect in the same context. Both effects are relevant for ethnically divided countries, and I focus on local mayoral elections, as they allow for comparison within the same country. With a recent history of ethnic conflict, and direct elections of the local mayors in several countries, the Western Balkans provide an interesting laboratory for this study. However, the centripetalist effect of majoritarian institutions functions only if electoral units are multi-ethnic (International Crisis Group 1998a: 7), which explains why the effects cannot necessarily be expected for presidential elections in countries with an overwhelming ethnic majority (Bose 2002: 235-7). ${ }^{7}$ I compare the outcomes of the Serbian parliamentary elections in 2003 to the mayoral elections in 2004, comparing the dynamics in the first and second round of the mayoral elections and across municipalities with a varying degree of ethnic heterogeneity.

Several authors have also investigated the mechanisms that led to the election of the Radical Party in Serbia in the post-authoritarian period (Stefanović 2008; Konitzer 2008). Konitzer, for his part, does not attempt to distinguish between group-specific voting behaviour and contextual effects. From his analysis of aggregated data, he concludes that different minority groups have different effects on the vote share of the Serbian Radicals. By contrast, Stefanović (2008) differentiates between group-effects and contextual effects. Using data from national presidential elections, he reports a curvilinear pattern of support for the Radical candidates. Hence, he suggests that support of Radical candidates increases in multiethnic environments. ${ }^{8}$ Differently, our study focuses on the effects of the ethnic context, and links them to the effect of the majoritarian electoral system. But before moving on to the empirical analysis of whether Key's effect has been present in Serbia, a short introduction to the Serbian party system is required, and an outline of the relevant institutional rules, most importantly the electoral system, in the period to which our study refers, 2003-4. 


\subsection{Characterising the dominant issues in the Serbian party system}

\section{Nationalising state}

(R):

The state is exclusively

for the titular nation.

Minorities are seen as hostile.

\author{
Moderate \\ nationalists \\ (DN)
}

\author{
Civic-liberal \\ orientation (D): \\ For equality of all \\ citizens.
}

\section{Ethnic minority \\ parties (E):}

Defending minority

rights or opting for separatism.
Domination of the titular nation

Hostility towards minorities
Rejection of majority dominance Stressing minority rights

Figure 1: The ethnic-nationalist dimension of party systems.

Nationalist-authoritarian values are one of the main pillars of political orientation in Serbia, and they also correlate strongly with other political issues (Bochsler 2010a). Figure 1 attempts to capture the ethnic-nationalist dimension of the Serbian party system, showing a continuous axis of positions which advocate a nationalising state and might even be hostile to ethnic minorities, to the advocates of ethnic minority rights and autonomy for ethnic minorities, which in the most pronounced cases might involve the calls for separatism. Figure 1 also identifies four political blocs, which are organised along this axis (see below).

Greater Serbia, the promotion of the Serbs as the dominant ethnic group, and the authoritarian rejection of civic liberalism were all highly salient on the Serbian political agenda in the 1990s. They were priorities for both Milošević's party, the Socialist Party of Serbia (SPS), and their ally, the Serbian Radical Party (SRS). Parties of the group of democratic reformers have also intermittently shared a majority nationalist orientation. Promoting Serbia as a civicliberal state has been in most periods the goal of the Democratic Party (DS), apart from short nationalist interludes. In the post-Milošević period, several issues related to the national question have dominated the agenda, namely the question of how to deal with the past and how to cooperate with the International Criminal Tribunal for the former Yugoslavia (ICTY), relationships with neighbouring states, minority rights, policies of non-discrimination, and democratic values. Most parties belonging to the Democratic reformers take somewhat civicliberal stands, with the exception of Democratic Party of Serbia (DSS) and the small New Serbia party (NS), both of which advocate a nationalizing state, promote a strong establishment of the Serbian Orthodox Church, and can be characterised as nationalist-conservative (Đurković 2007; Komšić 2003: 48).

These issues are also closely related to the regime conflict and to Serbian foreign policies. The two parties that were the pillars of the Milošević regime, SPS and SRS, belong to the 
authoritarian-nationalist field and used to be oriented towards Russia rather than the European Union, whereas among the pro-European reform parties, we find either the civic-liberal option (DS and the Serbian Renewal Movement, SPO), moderate nationalists (DSS and NS), or parties of ethnic minorities. The more recently formed G17+ and the Liberal-Democratic Party (LDP) have joined the reform-oriented side of the political spectrum. Around 2006, DSS and NS have moved away from the project of Western integration, looking for cooperation with Russia and opposing NATO membership.

To locate the political parties along this axis, I have asked three experts of party politics in Serbia. ${ }^{9}$ In general, four political blocs can be distinguished in Serbia at the period of investigation. First, there are the parties that most strongly advocate a nationalising state, and are designated as Radical forces (R). These include SRS and SPS, the Party of the Serbian Force (PSS), and two minor parties (SSJ, SNS). The second bloc, the moderate nationalists (DN), includes DSS, which in 2003/4, could neither be seen as part of the Radicals, nor of the civic-liberal parties. The third bloc, comprised of civic-liberal parties, encompasses the DS, G17+, SPO (which competed jointly with the New Serbia party (NS) in 2003) and several minor parties (RV, DHSS, Otpor, RSV, DA, LS). The Serbian denomination for these parties is the Democrats (D). Finally, the fourth bloc contains the parties of ethnic minorities (E), which stand extremely close to the civic-liberal parties. Occasionally, they may even offer joint lists with the Democrats or common candidates at different levels of elections. The Serbian party system underwent major shifts well after the period of investigation, in 2007/8.

\subsection{Ethnic minority parties}

Most ethnic minorities in Serbia live concentrated in different regions (figure 2). The major ethnic parties have been included in several democratically oriented cabinets since $2000 .{ }^{10}$ The largest ethnic minority in Serbia, the Hungarians (4\% of the population, concentrated overwhelmingly in the Vojvodina region) organised themselves under the Democratic Union of the Vojvodina Hungarians (DZVM) in 1990. In the 1990s, the party's controversial demand for territorial autonomy (Jenne 2004: 741-2) provoked several internal splits, at which point the Union of the Vojvodina Hungarians (SVM) became the most important Hungarian minority party. Since the 2000s, the Hungarian minority parties have increasingly begun to cooperate. They demand a substantial political and cultural autonomy for the eight municipalities in Northern Vojvodina that have a high concentration of ethnic Hungarians, but have never supported any secessionist claims. 


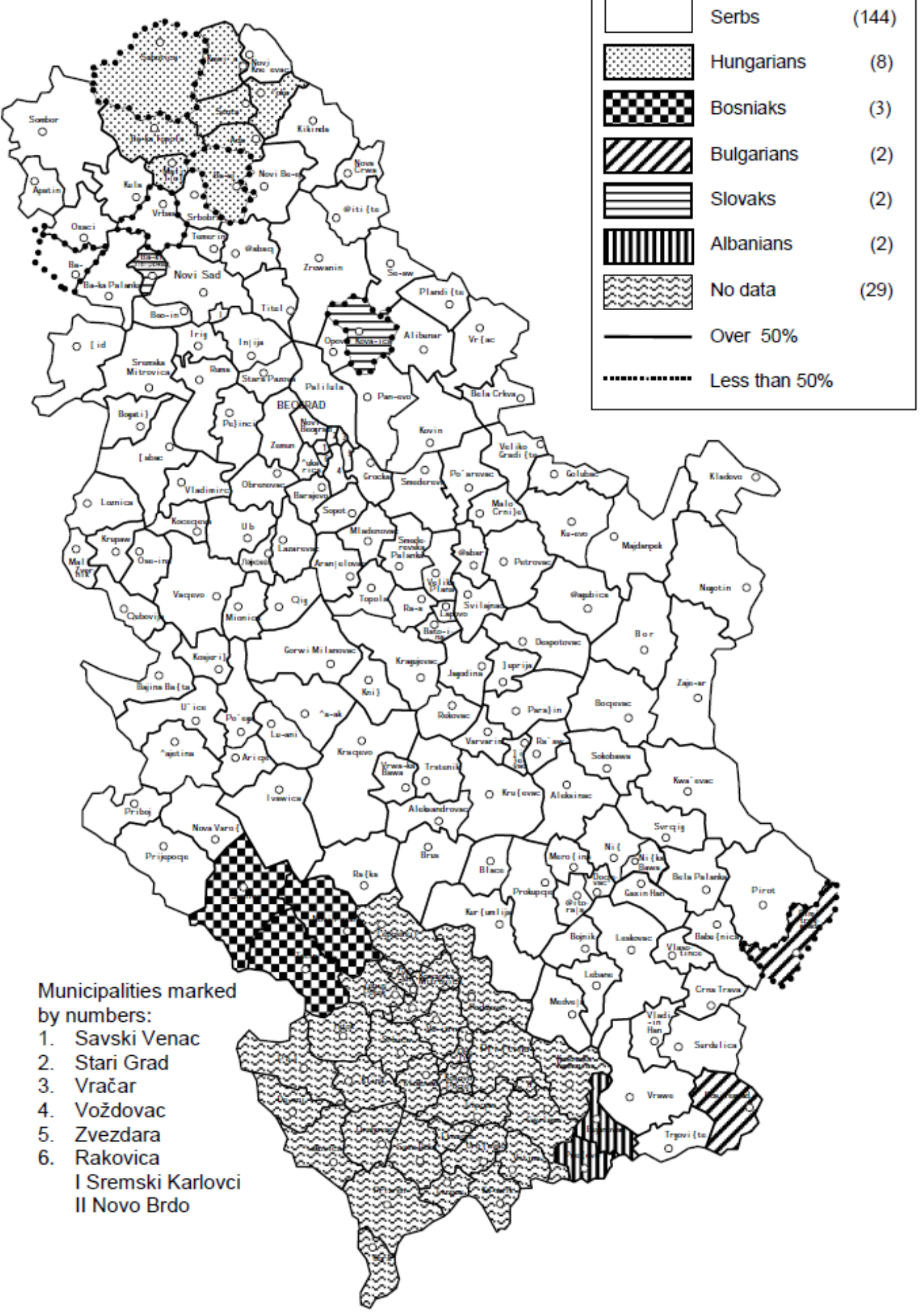

Figure 2: Ethnic map of Serbia and of Kosovo (no data).

Source: Republic Statistical Office of Serbia, Final Results of the Census 2002. Population by national or ethnic groups, gender and age groups in the Republic of Serbia, by municipalities.

The Sandžak, in the South of the country, is the second stronghold of ethnically oriented parties. It is mostly populated by a Bosniak minority of Serbo-Croat-speaking Muslims who comprise the largest ethnic group in neighbouring Bosnia. The first Bosniak party began as a 
local branch of the Party of Democratic Action (SDA) from Bosnia, and became independent when Bosnia seceded from the former Yugoslavia. SDA leader Sulejman Ugljanin, who organised a referendum for the political autonomy of the Sandžak region, was accused of trying to engineer Sandžak's secession from Serbia (ICG 1998b: 8) by Serbian politicians and the media. After a split in 1995, and the formation of the less radical Sandžak Democratic Party (SDP), the Bosniak political scene remains deeply divided and largely overshadowed by physical violence between members of both main party blocs (see also Szöcsik and Bochsler 2012).

The third notable region inhabited by an ethnic minority is the Albanian-dominated Preševo Valley. Ethnic Albanians ( $0.8 \%$ of the Serbian population) vote almost exclusively for several ethnically defined parties, although until 2007 they mainly boycotted national elections. After the introduction of a new electoral law, and the abolition of gerrymandered districts in the municipality of Bujanovac in 2002, ethnic Albanian parties control the local authorities both in Preševo and in Bujanovac, while the third Preševo Valley municipality, Medveđa, is controlled by a local Serbian majority.

Parties representing other minorities have remained small, focusing mainly on local politics; only in few instances have they won seats in the national parliament. Parties representing the Roma minority have occasionally won up to two seats out of the available 250. The political conflict with smaller minorities, such as Slovaks, Vlachs/Romanians, Croats, Bunjevac, Ukrainians or Russians, who live predominately in multi-ethnic Vojvodina, is much less pronounced (Bašić and Crnjanski 2006).

\subsection{Electoral law}

At the national level, the most important institutional restriction on the evolution of Serbia's party system is arguably the legal electoral threshold of 5 percent. While similar rules had been in place since the $1990 \mathrm{~s}$, they had applied to local electoral districts, and not nationally. This had allowed Hungarians, Bosniaks, and Albanians to pass the threshold in the districts where they were most highly concentrated. However since then, only the Hungarian minority parties have been able to achieve constant representation in the Serbian parliament. The shifting of the legal threshold in 2000 from the local to the national level excluded all minority parties from running independently in elections, but some of them have repeatedly reached the national parliament through electoral alliances, and they have remained represented in local and regional institutions. The consequences of the national legal threshold were partly reversed in 2007, when the threshold was lifted for ethnic minority parties (Bochsler 2008). 
Elections are also held in the autonomous Vojvodina province and everywhere at the municipal level. Municipal elections were scheduled in September 2004, and local parliaments (by PR) and local mayors were elected simultaneously. Mayors were elected in a two-round majority vote system; the two candidates with most votes entered the runoff. ${ }^{11}$ No municipal elections were held in Kosovo. Mayors of the Belgrade town municipalities were elected indirectly, and are excluded from this study. In the subsequent local elections in 2008, mayors were elected indirectly through the local parliaments.

\section{The 2004 mayoralty elections}

\subsection{The political colour of the elected mayors}

First, we compare the electoral results of the local mayoralty elections in September 2004 (table 1a) with the closest parliamentary elections in December 2003 (table 1b), looking at municipalities with varying concentrations of ethnic minorities.

The effect is illustrated in figure 3, showing the electoral results of Serbian nationalist parties from Serbian municipalities by their ethnic composition (share of minorities living in the municipality). The figure shows the results of the main nationalists (SRS) separately, and of the whole ultra-nationalist bloc. The lines on figure 3 shows the overall trend. As members of ethnic minorities only rarely vote for Serbian nationalists, one would initially expect that the vote share of Serbian nationalist parties is negatively correlated with the share of ethnic minorities in a municipality,. A radicalising effect of the ethnic structure on the voting behaviour of ethnic Serbs would alter this picture: although there are fewer Serbs living in multi-ethnic municipalities, compared to ethnic homogeneous ones, these are more likely to vote for nationalists, than those living in mono-ethnic places. This leads to curvilinear functions, which are clearly visible in figure 3.

The curvilinear effect emerges both in PR elections (figure 3, left-hand side), and in mayoral elections (right-hand side). The effect is a little more pronounced for the main radical party (SRS) than for the whole bloc. All of the Serbian nationalist parties demonstrate substantial support from municipalities with a very high share of ethnic minorities. ${ }^{12}$ As this happens also under PR, empirical evidence shows support for the threat hypothesis, which should apply regardless of the electoral system. 


\begin{tabular}{|c|c|c|c|c|c|c|c|c|c|}
\hline & & Elected & mayor & belongs & to party & coalition. & & & \\
\hline $\begin{array}{l}\text { Share of } \\
\text { ethnic } \\
\text { minorities }\end{array}$ & $\begin{array}{l}\text { Number of } \\
\text { municipalities }\end{array}$ & E & D-E & D & DN & $\mathrm{R}$ & \begin{tabular}{|l|} 
Local \\
citizens' \\
groups
\end{tabular} & others & Total \\
\hline $0-10 \%$ & 87 & 0 & 0 & 39 & 19 & 24 & 12 & 5 & 100 \\
\hline $10-20 \%$ & 14 & 0 & 0 & 12 & 3 & 63 & 22 & 0 & 100 \\
\hline $20-30 \%$ & 17 & 0 & 12 & 8 & 7 & 54 & 19 & 0 & 100 \\
\hline $30-40 \%$ & 11 & 0 & 0 & 29 & 5 & 54 & 12 & 0 & 100 \\
\hline $40-50 \%$ & 2 & 77 & 0 & 0 & 0 & 0 & 23 & 0 & 100 \\
\hline$>50 \%$ & 18 & 63 & 8 & 18 & 2 & 0 & 3 & 7 & 100 \\
\hline Total & 149 & 7 & 3 & 29 & 13 & 31 & 13 & 4 & 100 \\
\hline
\end{tabular}

Table 1a: Mayors by share of ethnic minority population in municipalities, 2004 local elections (all figures in percentages). Municipalities weighted by the number of registered voters.

$E=$ ethnic minority parties, $D=$ Democrats; $D-E=$ alliance of Democrats with ethnic minority parties; $D N=$ moderate nationalists; $R=$ Radicals.

\begin{tabular}{|c|c|c|c|c|c|c|c|}
\hline $\begin{array}{l}\text { Share of } \\
\text { ethnic } \\
\text { minorities }\end{array}$ & $\begin{array}{l}\text { Number of } \\
\text { municipalities }\end{array}$ & $\mathrm{E}$ & D & DN & R (all) & $\mathrm{R}(\mathrm{SRS})$ & Others \\
\hline $0-10 \%$ & 87 & 0 & 39 & 19 & 41 & 28 & 1 \\
\hline $10-20 \%$ & 14 & 3 & 31 & 14 & 50 & 38 & 1 \\
\hline $20-30 \%$ & 17 & 8 & 36 & 14 & 40 & 32 & 1 \\
\hline $30-40 \%$ & 11 & 11 & 32 & 13 & 43 & 34 & 1 \\
\hline $40-50 \%$ & 2 & 14 & 38 & 12 & 35 & 29 & 2 \\
\hline$>50 \%$ & 18 & 28 & 40 & 7 & 24 & 20 & 1 \\
\hline Total & 149 & 6 & 27 & 16 & | & م0 & 1 \\
\hline
\end{tabular}

Table 1b: Vote share in national parliamentary elections by PR (in 2003), all figures in percentages.
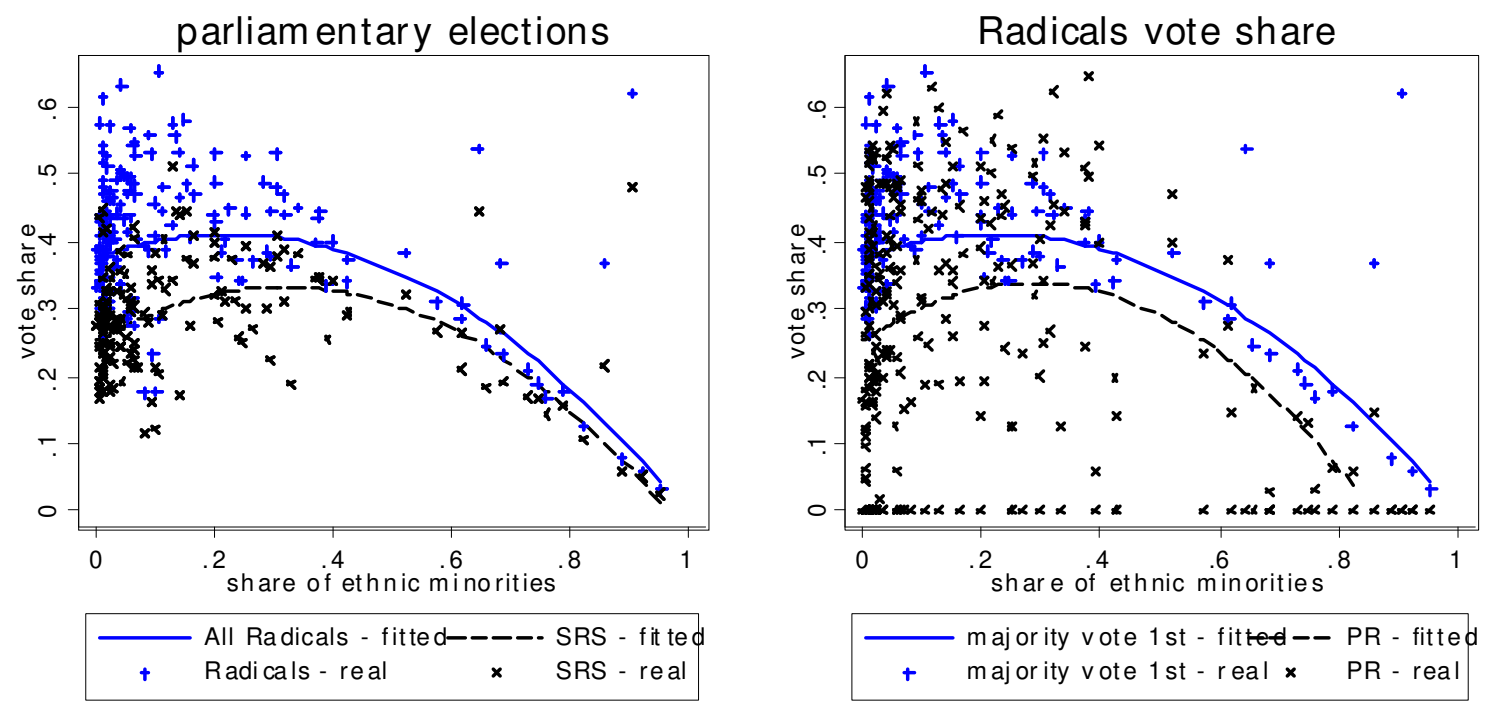

Figure 3: Municipalities by their share of ethnic minorities and Radical votes in the 2003 parliamentary elections (left graph), and comparing the parliamentary elections 2003 (by PR) with the mayoralty elections ( $1^{\text {st }}$ round, two-round majority vote) (right graph).

(The lines show fitted values, resulting from an Goodman OLS regression model, weighted by the number of voters per municipality, with the ethnic minority share and its square as explanatory variables.) 
The same pattern emerges for the first round of the two-round majority elections for the mayoral offices in 2004, though at a slightly lower level (perhaps because some $12 \%$ of the votes were cast for local citizens' groups, and 3\% of the vote went to other, unclassified small parties). Still, the two-round majority elections for the mayoral offices produced a victory for the Radicals in a large portion of the multi-ethnic municipalities. In ethnically homogeneous municipalities, by contrast, the Radicals proved able to win only a small portion of the mandates, below 10\% - far below their PR vote share-and the SRS could rarely win a mayoral office. By contrast, the Radicals' could with $40 \%-50 \%$ of the PR votes win $54 \%$ $63 \%$ of the mayor offices in these municipalities. The foremost beneficiary is the SRS (see table 1a). In municipalities where the ethnic minorities hold a local majority, the Radicals do not win any mayoral mandates. The discrepancy between PR elections and the two-round majority vote is patently clear.

The Democrats (D) perform well in mayoralty elections in homogeneous municipalities (those where less than 10 per cent of the electorate belong to minorities). There they won $39 \%$ of the mandates in the two-round majority elections, more than their vote share in PR elections. This would look even more impressive if other parties and local citizen groups had not won about a sixth of the mayoral offices in these municipalities. In ethnically mixed municipalities with a Serbian majority (10\%-40\% minorities), however, the Democrats win just $10-29 \%$ of the mayoral offices - much less than their vote share in PR elections of more than $30 \%$. The conservative-nationalist parties (DN)—which we locate between Democrats and Radicals on the ethnic-nationalist axis-win their mayoral offices predominantly in ethnically homogeneous municipalities. Ethnic minority parties (E) appear predominant in municipalities where minorities are closest to being a numerical majority (with more than $40 \%$ minority population). Apart from municipalities where ethnic minorities are a majority, minority parties take one additional office in a municipality with a strong ethnic minority (specifically, in the Sandžak municipality of Prijepolje, $45 \%$ minority population).

The results show clear evidence for both types of Key's effect: a general radicalisation effect of multi-ethnic contexts, which is accelerated by majoritarian voting systems. Democrats do well in ethnically homogeneous municipalities, and particularly so in the tworound majority vote for the mayor's office. The Radicals do best under the two-round majority vote in mixed-ethnic municipalities (10-40\% minorities). To rule out alternative explanations (specific concentrations of votes in certain municipalities, selective turnout, second-order effects, and party alliances) a few refining tests are needed. 


\subsection{Comparing the mayor election results with the PR elections by municipalities}

We further must confirm that the Radicals' victories do not stem from an uneven distribution of votes in the various municipalities (i.e. the results of intended or accidental 'gerrymandering'). If the distribution of voters could make a difference, then the winning candidate could be predicted by vote distribution under PR or from the first round election results. To rule this out, we analyse the municipalities according to the vote distribution in the parliamentary elections 2003 and in the first round of the 2004 mayor elections.

Table 2 displays the outcomes of the second round of the mayoral elections, ordered by the strength of the political blocs in the parliamentary elections in $2003,{ }^{13}$ and distinguishing municipalities where one political bloc holds an absolute majority. For each type of municipalities, we expect a different result of the two-round majority vote. The third expected effect is integral for illustrating the electoral system effect on radicalisation.

1. Party blocs that hold an absolute majority of the votes will either already wins in the first round or its candidate(s) will most likely enter the second round and win (all cases in the upper part of table 2). Most empirical observations in these groups of cases fit with our expectation.

2. In municipalities with no absolutely dominating bloc, and where the moderate nationalists (DN) are among the two strongest blocs, they are likely to enter in the second round of voting, and are expected to win in the runoff. However, there is only one exceptional case in this group ( $\mathrm{D}+\mathrm{E}>\mathrm{DN}>\mathrm{R})$, and a local citizens' group won the election. ${ }^{14}$

3. In all remaining cases, $\mathrm{D}+\mathrm{E}$ and $\mathrm{R}$ are the two largest blocs, but neither of them holds an absolute majority. In these cases $(\mathrm{R}>\mathrm{D}+\mathrm{E}>\mathrm{DN}$ or $\mathrm{D}+\mathrm{E}>\mathrm{R}>\mathrm{DN})$, we expect a runoff between candidates of $\mathrm{D}+\mathrm{E}$ and $\mathrm{R}$, with $\mathrm{DN}$ voters having the pivotal vote for either of the two candidates. These are the cases where Key's effect of ethnically oriented voters might come into play. Indeed, candidates of the blocs $\mathrm{D}+\mathrm{E}$ and $\mathrm{R}$ are the most frequent winners in these municipalities. 


\begin{tabular}{|c|c|c|c|c|}
\hline & $R>D N>D+E$ & $\mathrm{R}>\mathrm{D}+\mathrm{E}>\mathrm{DN}$ & $D+E>R>D N$ & $D+E>D N>R$ \\
\hline $\begin{array}{c}\text { who will enter } \\
2^{\text {nd }} \text { round? }\end{array}$ & $R$ versus $D N$ & $R$ versus $D+E$ & $D+E$ versus $R$ & $D+E$ versus $D N$ \\
\hline \multicolumn{5}{|l|}{ who will win? } \\
\hline \multicolumn{5}{|c|}{ absolute majority for largest bloc } \\
\hline expectation & $\mathrm{R}$ wins & $R$ wins & $D$ or $E$ wins & D or E wins \\
\hline empirical results & $\begin{array}{c}\text { no such } \\
\text { observations }\end{array}$ & $\begin{array}{c}\text { fits with } \\
\text { hypothesis: } 56 \% \\
\mathbf{R} \\
\text { Against hypothesis: } \\
14 \% \text { D; } 11 \% \text { E; } 6 \% \\
\text { DN; } \\
\text { Not classifiable: } \\
\text { 12\% local citizens' } \\
\text { groups; } 2 \% \text { others }\end{array}$ & $\begin{array}{c}\text { fits with } \\
\text { hypothesis: } \\
58 \% \text { E; } 23 \% \text { D; } \\
\mathbf{8 \%} \text { D-E; } \\
\text { Against hypothesis: } \\
2 \% \text { R; } \\
\text { Not classifiable: } \\
7 \% \text { others; } 3 \% \\
\text { local citizens. }\end{array}$ & $\begin{array}{c}\text { no such } \\
\text { observations }\end{array}$ \\
\hline \multicolumn{5}{|c|}{ no absolute majority } \\
\hline expectation & DN wins & $\begin{array}{c}\text { DN pivotal voter, } \\
\text { vote for } R \text { in divided } \\
\text { municipalities, for } D \\
\text { in homogeneous } \\
\text { ones }\end{array}$ & $\begin{array}{c}\text { DN pivotal voter, } \\
\text { vote for } R \text { in divided } \\
\text { municipalities, for } D \\
\text { in homogeneous } \\
\text { ones }\end{array}$ & DN wins \\
\hline empirical results & $\begin{array}{c}\text { no such } \\
\text { observations }\end{array}$ & $\begin{array}{c}44 \% ; 22 \% D ; \\
12 \% D N ; \\
\text { (see table } 3 \text { ) } \\
\text { Not classifiable: } \\
\text { 19\% local citizens; } \\
3 \% \text { others }\end{array}$ & $\begin{array}{c}38 \% D ; 18 \% R ; \\
17 \% D N ; 8 \% \text { E; } 6 \% \\
D-E \text { (see table } 3) \\
\text { Not classifiable: } \\
\text { 10\% local citizens; } \\
5 \% \text { others } \\
\end{array}$ & $\begin{array}{l}\text { Not classifiable: } \\
100 \% \text { local } \\
\text { citizens' groups } \\
\text { (only } 1 \\
\text { municipality) }\end{array}$ \\
\hline
\end{tabular}

Table 2: Classification of municipalities in Serbia according to the distribution of votes in the parliamentary elections 2003; expected and observed outcome in the mayoral elections.

This last group of municipalities, where the Democrats (incl. ethnic minority parties) and the Radicals are the two largest blocs, but neither of them holds an absolute majority of the vote, is the most relevant for our analysis. These cases also cover the largest number of municipalities in Serbia. For these municipalities, we look at the dynamics of the two-round elections, and distinguish them by their share of ethnic minorities (table 3 ). 


\begin{tabular}{|c|c|c|c|c|c|c|c|c|}
\hline minority share & nr obs & $D-E$ & D & DN & $\mathrm{R}$ & local citiz & other & Total \\
\hline & $N$ & $\%$ & $\%$ & $\%$ & $\%$ & $\%$ & $\%$ & $\%$ \\
\hline $0-10 \%$ & 69 & 0 & 42 & 21 & 21 & 12 & 5 & 100 \\
\hline $10-20 \%$ & 8 & 0 & 14 & 5 & 70 & 11 & 0 & 100 \\
\hline $20-30 \%$ & 12 & 14 & 5 & 9 & 51 & 22 & 0 & 100 \\
\hline $30-40 \%$ & 10 & 0 & 30 & 5 & 51 & 13 & 0 & 100 \\
\hline $40-50 \%$ & 1 & 0 & 0 & 0 & 0 & 100 & 0 & 100 \\
\hline$>50 \%$ & 2 & 0 & 53 & 48 & 0 & 0 & 0 & 100 \\
\hline Total & 102 & 3 & 32 & 16 & 31 & 14 & 4 & 100 \\
\hline
\end{tabular}

Table 3: Municipalities where $D+E$ and $R$ are the two largest plurality blocs; winners of the mayoral mandates, by share of ethnic minorities among the population. Municipalities weighted by their population.

In ethnically mixed municipalities, with $10-40 \%$ of ethnic minorities, the Radicals are much more successful than they are in ethnically homogeneous municipalities, even if their actual strength (in PR elections) is similar. As none of these municipalities has a high concentration of Radical voters, the Radicals seem to have profited from the two-round majority system.

By contrast, the Democrats became the strongest political party by far under the tworound majority vote in ethnically homogeneous municipalities. All told, they garnered $42 \%$ of the available mayoral offices, but - jointly with ethnic minority parties - only $14 \%-30 \%$ of the offices in ethnically mixed municipalities (10-40\% minorities).

Out of all 149 analysed Serbian municipalities, such cases, with no absolute majority for one party group represent 102 cases, or $77 \%$ of the population. Therefore, these municipalities, and the pivotal votes of the moderate Nationalists (DN) are decisive for the overall picture of the mayoralties in Serbia. Finally, in areas where minorities are dominant, and only in those areas, there is a clear majority for the Democrats and ethnic minority parties in PR elections (table 4). 


\begin{tabular}{|c|c|c|c|c|c|}
\hline \multirow{2}{*}{$\begin{array}{r}\text { Minority } \\
\text { share } \\
\end{array}$} & \multirow[b]{2}{*}{$\mathrm{Nr}$ of municipalities } & \multicolumn{3}{|c|}{ Absolute majority of PR vote for... } & \multirow[b]{2}{*}{ Total } \\
\hline & & $\mathrm{R}$ & $D+E$ & none & \\
\hline$\%$ & $\mathrm{~N}$ & $\%$ & $\%$ & $\%$ & $\%$ \\
\hline $0-10$ & 87 & 11 & 0 & 89 & 100 \\
\hline $10-20$ & 14 & 41 & 0 & 59 & 100 \\
\hline $20-30$ & 17 & 9 & 5 & 85 & 100 \\
\hline $30-40$ & 11 & 5 & 0 & 95 & 100 \\
\hline $40-50$ & 2 & 0 & 77 & 23 & 100 \\
\hline$>50$ & 18 & 12 & 84 & 3 & 100 \\
\hline & 149 & 12 & 11 & 77 & 100 \\
\hline
\end{tabular}

Table 4: Municipalities, according to the majority of votes for political blocs in PR elections, percentage. (Municipalities weighted by their size.)

This does not rule out second-order effects (systematic differences between national and local elections), turnout effects, or more idiosyncratic explanations (e.g., voters relying on the personality of certain candidates or on local political dynamics). However, second-order effects at the local level would likely occur homogeneously throughout the country, and would hardly drive such a discernible pattern in ethnically homogeneous and ethnically mixed environments. Also, alternative explanations might have difficultly explaining how the observed radicalisation effect does not only occur when comparing with the parliamentary elections in the previous year, but the effect similarly occurs between the first and the second round of the mayoral elections (for detailed results, see supplementary material provided on the author's webpage).

Often, in 39 municipalities, we find pairings of Democrats versus Radicals in the runoff election (in other cases, DN candidates or local citizens' group candidates make it to the $2^{\text {nd }}$ round). Most often, the larger of the two blocs wins, but the ethnic structure also plays a crucial role (see tables $5 \& 6$ ). Radical candidates prove more successful in ethnically mixed municipalities than in ethnically homogeneous municipalities. In ethnically homogeneous municipalities, if Democrats lead in the first round of the elections (left-hand table, D+E $>R$ ), then they typically emerge victorious in the second round, occasionally even if the Radicals were stronger in the first round (right-hand table, $\mathrm{R}>\mathrm{D}+\mathrm{E}$ ). Conversely, the Radicals seem to gain votes in the second round of elections in mixed-ethnic municipalities: Radical candidates, who led after the first round, are almost always elected. 


\section{$\mathrm{D}+\mathrm{E}>\mathrm{R}>\mathrm{DN}$}

\begin{tabular}{l|r|r|r|l}
$\begin{array}{l}\text { share of } \\
\text { minorities }\end{array}$ & $\begin{array}{l}\text { number of } \\
\text { observations }\end{array}$ & D & $R$ & $R$ \\
\hline $0-10 \%$ & $\mathrm{~N}$ & $\mathrm{~N}$ & $\mathrm{~N}$ & $\%$ \\
\hline $10-20 \%$ & 3 & 10 & 3 & 23 \\
\hline $20-30 \%$ & 3 & 1 & 2 & 67 \\
\hline $30-40 \%$ & 2 & 1 & 1 & 50 \\
\hline & & & & \\
\hline Total & 21 & 14 & 7 & 33
\end{tabular}

$\mathrm{R}>\mathrm{D}+\mathrm{E}>\mathrm{DN}$

\begin{tabular}{l|r|r|l|l|l}
$\begin{array}{l}\text { share of } \\
\text { minorities }\end{array}$ & $\begin{array}{l}\text { number of } \\
\text { observations }\end{array}$ & D-E & D & $R$ & $R$ \\
\hline & N & N & N & N & $\%$ \\
\hline $0-10 \%$ & 9 & 0 & 3 & 6 & 67 \\
\hline $10-20 \%$ & 2 & 0 & 0 & 2 & 100 \\
\hline $20-30 \%$ & 3 & 1 & 0 & 2 & 67 \\
\hline $30-40 \%$ & 4 & 0 & 0 & 4 & 100 \\
\hline & & & & & \\
\hline Total & 18 & 1 & 3 & 14 & 78
\end{tabular}

Tables 5 \& 6: Who wins if a Democrat runs against a Radical in the second round? Municipalities with by share of ethnic minorities among the population.

Since there are only minor differences in turnout between the two rounds, ${ }^{15}$ and since there is no plausible explanation for selective de-mobilisation and mobilisation between the two rounds, the turnout explanation can safely be ruled out. Hence, our results strongly indicate that Key's effect is in play, and that it has a particularly strong effect under the two-round majoritarian vote in Serbia. In mixed-ethnic municipalities, many voters might perceive the Democrats as too liberal and minority-friendly to vote for, and lean instead towards the Radicals. One catalyst for this conflict appears to be the animosity between the main protagonist of the moderate nationalists, the DSS, and a regional party of the Democrats, the League of Vojvodina Social Democrats (LSV), which takes positions that are very close to ethnic minorities and is particularly strong in the multiethnic Vojvodina region. ${ }^{16}$ The Democrats' and the moderate nationalists' diverging views on ethnic issues appear to have fostered alienation in this multi-ethnic environment. In ethnic homogeneous municipalities, where ethnic issues are not salient, these differences between the Democrats and the moderate nationalists do not emerge as important.

\section{Conclusions}

Radicalisation effects in elections in multi-ethnic environments have been well documented in the existing literature, and-as mentioned earlier-they have been frequently discussed as they pertain to post-WWII state elections in the southern United States. Research going back to Key (1949) and Keech (1968) has shown a paradox of voting behaviour in ethnically or racially divided communities. Key's effect addresses the phenomenon of how elected politicians are less minority-friendly in these communities than in ethnically homogeneous units in territorial units with a higher degree of minorities. This study demonstrates a similar 
effect for recent elections in Serbia. The country is not only ethnically divided, but it also allows a comparison of electoral system effects across different types of municipalities. In carrying out this comparison, our research has suggested a new argument concerning the impact of Serbia's electoral system on the process of ethnic radicalisation. The radicalisation effect occurs both under PR and under the two-round majoritarian system, but it is considerably stronger in the latter case.

Two types of arguments can provide an explanation.

First, we have observed that Radicals - who are the most pronounced advocates of a nationalizing state - tend to get larger vote shares in ethnically split places, compared to ethnically homogeneous places. This represents a clear manifestation of radicalisation, present under any electoral systems: Voters in multi-ethnic environments tend to have nationalist views more often than those in ethnically homogeneous places.

Nevertheless, the Radicals can rely only in rare cases on a majority of the first preferences of the voters, which would allow them to win the office in the first round of the mayoral elections. Instead, the Radicals enjoy a disproportionate rise in votes between the first and the second round of the majority vote elections in ethnically divided places. Most often, Radical candidates were entering the runoff against Democrats. While the Democrats typically won such races when campaigning in homogeneous environments, in multi-ethnic municipalities, the Radicals were able to attract more additional votes than the Democrats, from voters who did not vote for either of these blocs in the first round. Apparently, voters in an ethnically mixed environment who do not clearly belong to either major party were more prone to opt for the Radicals in a two-candidate runoff. By contrast, in ethnically homogeneous municipalities, the Democrats were more favoured to win these votes.

This second type of radicalisation occurs only in two-round majoritarian systems (and, possibly, in other majoritarian electoral systems with an absolute majority threshold). Under this voting system elections are decided between the two front-running candidates. In multiethnic places, ethnically oriented voters of the majority defect from the more moderate candidate, as they perceive her to be heavily supported by voters belonging to the ethnic minority. In the Serbian case, Democrat and Radical candidates compete against each other in the second round, and moderate nationalists (the Democratic Party of Serbia, DSS) have the decisive vote. In line with the model of ethnically oriented voters, they tend to support the Radicals in multi-ethnic contexts. In ethnically homogeneous places, however, where no members of the minority vote, they seem to vote for the moderate candidates. This corresponds closely to the ethnic backlash effect that has been observed in majoritarian voting 
elsewhere. This second effect explains why the two-round majority vote - to a much greater extent than PR - tends to help elect Radicals in ethnically mixed municipalities, and to elect Democrats in ethnically homogeneous municipalities.

These conclusions present a rather pessimistic view of whether electoral engineers can actually use majoritarian voting systems to reduce ethnic conflicts in deeply divided societies. These findings appear to be in line with other research in this area (Bose 2002: 234); similar effects have been reported in other political contexts, even where the ethnic division is not as deep as it is in Serbia. Our empirical documentation of the reinforcement of ethnic radicalisation through the majority vote is new, however. The same effects might possibly apply under similar electoral systems, such as the Alternative Vote, if applied in divided societies. An important avenue for further research would be the empirical investigation of the properties of other majority voting systems, and whether they can provide incentives that help to escape the radicalising effect of the two-round majority vote. This, however, would present its difficulties, given the difficulty of studying the effects of an electoral system that has hardly ever been applied for elections - let alone in countries that fit the description of a divided society. 


\section{References}

Andweg, Rudy B. 2000. 'Consociational democracy.' Annual Review of Political Science 3:509-36.

Barany, Zoltan. 2001. 'Romani Electoral Politics and Behaviour.' Journal on Ethnopolitics and Minority Issues in Europe.

Bašić, Goran, and Katarina Crnjanski. 2006. Politička participacija i kulturna autonomija nacionalnih manjina u Srbiji. Beograd: Friedrich Ebert Stiftung/Centar za istraživanje etniciteta.

Birch, Sarah. 2003. 'Two-round electoral systems and democracy.' Comparative Political Studies 36 (3):319-44.

Birnir, Jóhanna Kristin. 2007. Ethnicity and Electoral Politics. Cambridge: Cambridge University Press.

Black, Merle. 1978. 'Racial Composition of Congressional Districts and Support for Federal Voting Rights in the American South.' Social Science Quarterly 59 (3):435-50.

Blalock, Hubert M. 1967. Toward a Theory of Minority-Group Relations. New York: Wiley.

Bochsler, Daniel. 2008. 'The parliamentary elections in Serbia, 21 January 2007.' Electoral Studies 27 (1):160-5.

2010a. 'The party system of Serbia.' In Party politics in the Western Balkans, ed. V. Stojarová and P. Emerson. Abingdon: Routledge.

2010b. 'Regional party systems in Serbia.' In Party politics in the Western Balkans, ed. V. Stojarová and P. Emerson. Abingdon: Routledge.

Bogaards, Matthijs. 2003. 'Electoral Choices for Divided Societies: Multi-Ethnic Parties and Constituency Pooling in Africa.' Commonwealth \& Comparative Politics 41 (3):59-80.

Bose, Sumantra. 2002. Bosnia After Dayton. London: Hurst.

Chandra, Kanchan. 2004. Why Ethnic Parties Succeed. Patronage and Ethnic Head Counts in India. Cambridge: Cambridge University Press.

2005. 'Ethnic Parties and Democratic Stability.' Perspectives on Politics 3 (2):235-52.

Doorenspleet, Renske. 2005. 'Electoral Systems and Good Governance in Divided Countries.' Ethnopolitics 4 (4):365-80.

Đurković, Miša. 2007. 'Narodnjaštvo u političkim strankama Srbije.' In Ideologija i političke stranke u Srbiji, ed. Z. Lutovac. Beograd: Friedrich Ebert Stiftung/Institut društvenih nauka.

Fraenkel, Jon, and Bernard Grofman. 2004. 'A neo-Downsian model of the alternative vote as a mechanism for mitigating ethnic conflict in plural societies.' Public Choice 121 (3-4):487-506. 2006a. 'Does the Alternative Vote Foster Moderation in Ethnically Divided Societies? The Case of Fiji.' Comparative Political Studies 39 (5):623-51.

2006b. 'The Failure of the Alternative Vote as a Tool for Ethnic Moderation in Fiji. A Rejoinder to Horowitz.' Comparative Political Studies 39 (5):663-6.

Gerber, Elisabeth R., Rebecca B. Morton, and Thomas A. Rietz. 1998. 'Minority Representation in Multimember Districts.' American Political Science Review 92 (1):127-44.

Glazer, Amihai, Bernard Grofman, and Guillermo Owen. 1998. 'A neo-Downsian model of grouporiented voting and racial backlash.' Public Choice 97:23-34.

Grofman, Bernard. forthcoming. 'Electoral Rules and Ethnic Representation and Accommodation: Combining Social Choice and Electoral System Perspectives.' In Power-Sharing in Deeply Divided Places, ed. J. McEvoy and B. O'Leary. Philadelphia: University of Pennsylvania Press.

Grofman, Bernard, Robert Griffin, and Amihai Glazer. 1992. 'The Effect of Black Population On Electing Democrats and Liberals To the House of Representatives.' Legislative Studies Quarterly XVII (3):365-79.

Grofman, Bernard, and Lisa Handley. 1995. 'Racial context, the 1968 Wallace vote, and southern presidential dealignment: evidence from North Carolina and elsewhere.' In Spatial and Contextual Models in Political Research., ed. M. Eagles. London: Taylor and Francis.

Grofman, Bernard, and Robert Stockwell. 2003. 'Institutional design in plural societies: Mitigating ethnic conflict and fostering stable democracy ' In Economic welfare, international business and global institutional change, ed. R. Mudambi, P. Navarra, G. Sobbrio, R. Mudambi, P. Navarra and G. Sobrio. Cheltenham: Elgar.

Hartzell, Caroline, and Matthew Hoddie. 2003. 'Institutionalizing Peace: Power Sharing and Post-Civil War Conflict Management.' American Journal of Political Science 47 (2):318-32.

Helsinki Committee for Human Rights in Serbia. 2004. "Vojvodina: getoizacija manjina." In Belgrade, media communication, 27 May 2004.

http://www.helsinki.org.yu/focus_text.php?lang=sr\&idteks=1287.

Horowitz, Donald L. 1985. Ethnic Groups in Conflict. Berkeley, Los Angeles, London: University of California Press. 
1991. A Democratic South Africa? Constitutional Engineering in a Divided Society. Berkeley: University of California Press.

2003. 'Electoral Systems: A Primer for Decision Makers.' Journal of Democracy 14 (4):115-27.

International Crisis Group. 1998a. "Changing the logic of Bosnian Politics: ICG Discussion Paper on

Electoral Reform." Sarajevo: International Crisis Group.

1998b. Sandzak: Calm for now. Sarajevo: ICG.

2005. "Serbia's Sandžak: Still Forgotten." In Europe Report No. 162. Belgrade/Brussels: Crisis Group.

Jenne, Erin. 2004. 'A Bargaining Theory of Minority Demands: Explaining the Dog that Did not Bite in 1990s Yugoslavia.' International Studies Quarterly 48:729-54.

Keech, William R. 1968. The Impact of Negro Voting. The Role of the Vote in the Quest for Equality. Chicago: Rand Mc Nailly.

Key, Vladimir O. 1949. Southern Politics in State and Nation. New York: Vintage.

Komšić, Jovan. 2003. 'Istorijsko-etnički rascepi i politička pregrupisavanja u Srbiji.' In Osnovne linije partijskih podela i mogući pravci političkog pregrupisavanja u Srbiji, ed. J. Komšić, D. Pantić and Z. Đ. Slavujević. Beograd: Friedrich Ebert Stiftung/Institut društvenih nauka.

Konitzer, Andrew. 2008. 'The Serbian Radical Party in the 2004 Local Elections.' East European Politics and Societies $22(4): 738-56$.

Lijphart, Arend. 1968. The Politics of Accomodation. Pluralism and Democracy in the Netherlands. Berkeley/Los Angeles: University of California Press.

1986. 'Proportionality by Non-PR Methods: Ethnic Representation in Belgium, Cyprus, Lebanon, New Zealand, West Germany and Zimbabwe.' In Electoral Laws and Their Political Consequences, ed. B. Grofman and A. Lijphart. New York: Agathon Press.

— 1994. 'Prospects for Power-Sharing in the New South Africa.' In Election '94 South Africa: The Campaign, Results and Future Prospects, ed. A. Reynolds. Cape Town, Johannesburg: David Philip.

2004. 'Constitutional Design for Divided Societies.' Journal of Democracy 15 (2):96-109.

Lublin, David. 1999. 'Racial Redistricting and African-American Representation. A Critique of "Do Majority-Minority Districts Maximize Substantive Black Representation in Congress?".' American Political Science Review 93 (1):183-6.

Nordlinger, Eric A. 1972. Conflict Regulation in Divided Societies. Cambridge (MA): Harvard University, Center for International Affairs.

Norris, Pippa. 2004. Electoral Engineering. Voting Rules and Political Behaviour. Cambridge: Cambridge University Press.

2005. Stable democracy and good governance in divided societies: Do power-sharing institutions work? Paper read at International Studies Association, 46th annual convention, 5 March, at Honolulu.

Olzak, Susan. 1986. 'A Competition Model of Ethnic Collective Action in American Cities, 1877-1889.' In Competitive Ethnic Relations, ed. S. Olzak and J. Nagel. Orlando (FL): Academic Press.

Reilly, Benjamin. 2001. Democracy in Divided Societies. Electoral Engineering for Conflict Management. Cambridge: Cambridge University Press.

. 2002. 'Electoral Systems for Divided Societies.' Journal of Democracy 13 (2):156-70.

Reynolds, Andrew. 2006. "Electoral systems and the protection and participation of minorities." Minority Rights Group International.

Richardson, Lilliard E. Jr, and Christopher A. Cooper. 2003. "The Mismeasure of MMD: Reassessing the Impact of Multi Member Districts on Descriptive Representation in U.S. State Legislatures." In 3rd annual conference on state politics and policy. Tucson, AZ.

Rule, Wilma, and Joseph Zimmerman, F., eds. 1994. Electoral Systems in Comparative Perspective. Their Impact on Women and Minorities. Westport: Greenwood Press.

Scarrow, Howard A. 1999. 'The impact of at-large elections: vote dilution or choice dilution?' Electoral Studies 18 (4):557-67.

Sisk, Timothy. 1996. Power Sharing and International Mediation in Ethnic Conflict. Washington DC: United States Institute of Peace.

Stefanović, Djordje. 2008. 'The path to Weimar Serbia? Explaining the resurgence of the Serbian far right after the fall of Milosevic.' Ethnic and Racial Studies 38 (7):1195-221.

Szöcsik, Edina, and Daniel Bochsler. 2012. 'All jointly or everyone on its own? On fissions and fusions of ethnic minority parties.' In New Nation-States and National Minorities, ed. J. Danero Iglesias, N. Stojanović and S. Weinblum. Colchester: ECPR Press.

Tolbert, Caroline J. 2003. 'Revisiting the Racial Threat Hypothesis: White Voter Support for California's Proposition 209.' State Politics and Policy Quarterly 3 (2):183-202. 
Tronconi, Filippo. 2006. 'Ethnic Identity and Party Competition. An Analysis of the Electoral Performance of Ethnoregionalist Parties in Western Europe.' World Political Science Review 2 (2):137-63.

Van Cott, Donna Lee. 2005. From Movements to Parties in Latin America: The Evolution of Ethnic Politics. New York: Cambridge University Press.

Wright, Gerald C. 1977. 'Contextual Models of Electoral Behavior: The Southern Wallace Vote.' American Political Science Review 71 (2):497-508. 
${ }^{1}$ If no candidate won an absolute majority of the votes in the first round, then a runoff election decided between the two strongest candidates.

${ }^{2}$ At the time of the local elections in 2004, there were incidents against the ethnic Hungarian minority in the Vojvodina region (Helsinki Committee for Human Rights in Serbia 2004), and the Sandžak region remained highly destabilised, and several players having "a vested interest to keep ethnic tensions at a high level" (International Crisis Group 2005).

${ }^{3}$ Although ethnic differences are constructed, ethnic groups can often times be distinguished by language, religion, race, or traditional habits and rites.

${ }^{4}$ Note that the term 'multi-ethnic parties' is applied only to parties that include the main ethnic groups that make up part of the ethnic conflict (Horowitz 1985: 299).

${ }^{5}$ Bogaards (2003) offers a different view, focussing on African countries.

${ }^{6}$ Barany (2001: 4) provides anecdotal evidence for similar processes under PR.

${ }^{7}$ In the Fiji case, the proponents of the Alternative Vote established the threshold for centripetalist effect around 10-12\% (Horowitz, cited in Fraenkel and Grofman 2006a: 627).

${ }^{8}$ However, the models presented in the study do not reveal any racial backlash effect, as defined here, but rather a positive correlation of the Radicals' strength and the share of the minority population. The second derivate is only weakly negative, so that Stefanović's result suggest that the Radicals' support is highest in an environment that is populated solely by an ethnic minority, and the marginal effect of an increase in the minority population would still be positive

${ }^{9}$ Two questions were asked, addressing the parties' attitudes towards ethnic minorities and the definition of the nation-state and the positions regarding dealing with war crimes committed in the recent wars in former Yugoslavia (a topic closely related to ethnic relations in Serbia). The answers of the three experts correlated at rates of $0.85-0.97$, and between the two questions at rates of $0.77-0.81$. Results are reported in the online appendix A (available on the author's webpage, www.bochsler.eu).

${ }^{10}$ This paragraph relies partly on Bochsler (2010b).

${ }^{11}$ Only in 6 municipalities (out of 149), a candidate was elected in the first round of the elections.

${ }^{12}$ Ethnic data according to the population census 2002. As ethnic majority, we consider persons who declare as Serbs, Yugoslavs, and Montenegrins (perceived to be close to Serbs), and persons with unknown ethnicity.

For three municipalities of the town Niš, the ethnic composition of the whole town is assumed $(94.6 \%$ ethnic majority).

As parts of the ethnic Albanian population have boycotted the parliamentary elections, the two heavily Albanian populated municipalities in the Preševo valley (Preševo, Bujanovac) do not fit the regression line. A further outlier is the Bulgarian-populated municipality of Bosilegrad, where the Radicals are not stronger than at the national average. Ethnic Bulgarians are only weakly organised politically.

${ }^{13}$ We show here the comparison based on the results of the PR elections, rather than the first round of the tworound mayor elections. The presence of candidates and/or the vote returns of the first round of mayoralty elections might be affected by strategic effects, and/or by the hypothesised effect of majoritarian elections.

${ }^{14}$ If we rely on the votes in the first round mayor elections in order to classify the cases (and these results occasionally deviate slightly from the parliamentary elections), we find a few further cases.

${ }^{15}$ In municipalities with a runoff between a Democrat or an ethnic minority candidate, and a Radical, turnout dropped on average only $1 \%$ from the first to the second round of elections (standard deviation $0.9 \%$ ). The maximal decrease in turnout amounts to $3.3 \%$, the maximal increase to $2.0 \%$.

${ }^{16}$ Information gained through expert interviews in Novi Sad and Belgrade, April 2007. 